\title{
PENERAPAN MODEL PEMBELAJARAN CONTEXTUAL TEACHING AND LEARNING SEBAGAI UPAYA UNTUK MENINGKATKAN PRESTASI MATEMATIKA MATERI PELUANG
}

\author{
Sukinah \\ SMP Negeri 33 Surabaya \\ sukinahiskan@gmail.com
}

\begin{abstract}
Abstrak
Bagaimanakah caranya agar peserta didik tidak melupakan materi pelajaran yang telah diterimanya agar peserta didik nantinya siap menghadapi ujian kenaikan kelas yang siap atau tidak siap harus mereka hadapi. Bagaimanakah membuat suatu materi ajar agar tidak terlupakan oleh anak didik. Dalam hal ini guru harus mencari metode untuk mengingatkan segala memori di benak peserta didik yang telah mereka terima. Guru harus bisa membangkitkan kembali memori itu.

Penelitian ini berdasarkan permasalahan: bagaimana tingkat penguasaan materi pelajaran matematika,tingkat penguasaan materi yang telah diterima peserta didik dalam menghadapi ujian kelulusan, pengaruh model pembelajaran Contextual Teaching and Learning pada materi pelajaran matematika yang telah dipelajari peserta didik.

Tujuan dari penelitian ini adalah: mengetahui tingkat penguasaan materi pelajaran matematika ,tingkat penguasaan materi pelajaran matematika yang telah diterima peserta didik dalam menghadapi ujian kenaikan kelas, pengaruh model pembelajaran Contextual Teaching and Learning pada materi pelajaran matematika yang telah dipelajari peserta didik.

Penelitian ini menggunakan penelitian tindakan (action research) sebanyak dua putaran. Setiap putaran terdiri dari empat tahap yaitu: rancangan, kegiatan dan pengamatan, refleksi, dan revisi. Sasaran penelitian ini adalah peserta didik kelas IX E SMP Negeri 33 Surabaya. Data yang diperoleh berupa hasil tes formatif, lembar observasi kegiatan belajar mengajar.

Dari hasil penelitian ini dapat disimpulkan bahwa model pembelajaran Contextual Teaching and Learning dapat meningkatkan kualitas pembelajaran matematika, memiliki dampak positif dalam meningkatkan prestasi belajar peserta didik materi "Peiluang"dengan peningkatan ketuntasan belajar peserta didik dalam setiap siklus, yaitu siklus I 75,68, sklus II 100\%, mempunyai pengaruh positif, yaitu dapat meningkatkan prestasi belajar peserta didik.
\end{abstract}

Kata Kunci : Prestasi Belajar, Model Pembelajaran, Contextual Teaching and Learning.

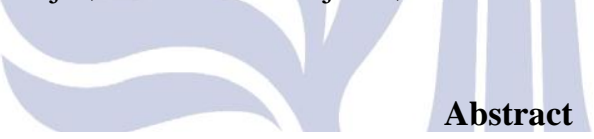

How can my students not to forget the subject matter that has received so that learners will be ready to face the test of the increase in class ready or not they must face. How to create a teaching material in order not to be forgotten by the students. In this case the teachers should find methods to remind all the memory in the minds of learners they have received. Teachers should be able to revive the memory of it.

This study is based on the problem: how the level of mastery of the subject matter of mathematics, the level of mastery of the material that has been received by the students in the exam graduation, influence learning model Contextual Teaching and Learning in the subject matter that has been studied mathematics learners.

The purpose of this research is to know the level of mastery of the subject matter of mathematics, the level of mastery of the subject matter of mathematics that has been accepted students in the exam class rise, influence learning models Contextual Teaching and Learning in the subject matter that has been studied mathematics learners.

This study uses action research (action research) as much as two rounds. Each round consists of four phases: design, activities and observation, reflection, and revision. Goal of this research is the students of class IX E SMP Negeri 33 Surabaya. The data obtained as the result of formative tests, observation sheet teaching and learning activities.

From these results it can be concluded that the learning model Contextual Teaching and Learning can improve the quality of mathematics learning, have a positive impact in improving learning achievement of learners material "Peiluang" to increase the thoroughness of learners in each cycle, the first cycle of 75.68 , sklus II $100 \%$, have a positive effect, which can improve the performance of learners.

Keywords: Achievement, Learning Model, Contextual Teaching and Learning.

\section{PENDAHULUAN}

Akhir dari rangkaian proses belajar mengajar adalah tes akhir suatu mata pelajaran yang dilakukan melalui tes formatif, tes akhir cawu, tes akhir semester atau tes ujian kenaikan kelas bagi peserta didik Kelas IX SMP. Di dalam menghadapi tes ujian kelulusan bagi peserta didik Kelas IX SMP perlu adanya refreshing terhadap materi ajar yang telah diterima oleh peserta didik selama mengikuti proses belajar mengajar.

Bagaimanakah caranya agar peserta didik tidak melupakan materi pelajaran yang telah diterimanya agar 
peserta didik nantinya siap menghadapi ujian kenaikan kelas yang siap atau tidak siap harus mereka hadapi. Bagaimanakah membuat suatu materi ajar agar agar tidak terlupakan oleh anak didik. Dalam hal ini guru harus mencari metode untuk mengingatkan segala memori di benak peserta didik yang telah mereka terima. Guru harus bisa membangkitkan kembali memori itu.Pendidikan matematika merupakan salah satu fondasi dari kemampuan sains dan teknologi. Pemahaman terhadap matematika, dari kemampuan yang bersifat keahlian sampai kepada pemahaman yang bersifat apresiatif akan berhasil mengembangkan kemampuan sains dan teknologi yang cukup tinggi (Buchori, 2001:120-121). Mengingat pentingnya matematika dalam pengembangan generasi melalui kemampuan mengadopsi maupun mengadakan inovasi sains dan teknologi di era globalisasi, maka tidak boleh dibiarkan adanya anak-anak muda yang buta matematika. Kebutaan matematika yang dibiarkan menjadi suatu kebiasaan, membuat masyarakat kehilangan kemampuan berpikir secara disipliner dalam menghadapi masalah - masalah nyata. Pendidikan merupakan proses untuk membantu manusia dalam mengembangkan dirinya dan untuk meningkatkan harkat dan martabat manusia, sehingga manusia mampu untuk menghadapi setiap perubahan yang terjadi, menuju arah yang lebih baik. Pembelajaran adalah membelajarkan peserta didik menggunakan asas pendidikan maupun teori belajar merupakan penentu utama keberhasilan pendidikan. Pembelajaran merupakan proses komunikasi dua arah, mengajar dilakukan oleh pihak guru sebagai pendidik, sedangkan belajar dilakukan oleh peserta didik atau murid (Syaiful Sagala, 2006 : 61). Dalam mata pelajaran matematika, sebagai upaya agar materi yang disampaikan benar-benar dapat diterima dan dikuasai oleh peserta didik dapat dilakukan dengan memberikan soal-soal, baik berupa soal cerita maupun soal objektif. Konsep-konsep yang diajarkan dikelas kurang dipahami oleh peserta didik, sehingga kemampuan peserta didik dalam menyelesaikan soal matematika masih kurang, ini membuat atau menjadikan peserta didik malas belajar matematika. Proses pembelajaran membutuhkan metode yang tepat. Kesalahan menggunakan metode, dapat menghambat tercapainya tujuan pendidikan yang diinginkan. Dampak yang lain adalah rendahnya kemampuan bernalar peserta didik dalam pembelajaran matematika. Hal ini disebabkan karena dalam proses peserta didik kurang dilibatkan dalam situasi optimal untuk belajar, pembelajaran cenderung berpusat pada guru, dan klasikal. Selain itu peserta didik kurang dilatih untuk menganalisis permasalahan matematika, jarang sekali peserta didik menyampaikan ide untuk menjawab pertanyaan bagaimana proses penyelesaian soal yang dilontarkan guru.Dari beberapa model pembelajaran, ada model pembelajaran yang menarik dan dapat memicu peningkatan penalaran peserta didik yaitu model pembelajaran CTL. Pada dasarnya, pembelajaran CTL adalah suatu sistem pengajaran yang cocok dengan otak yang menghasilkan makna dengan menghubungkan muatan akademik dengan konteks dari kehidupan seharihari peserta didik.Menurut Rudi Hartono CTL adalah konsep pembelajaran yang menekankan pada keterkaitan materi pembelajaran dengan dunia kehidupan siswa secara nyata, sehingga ia mampu menghubungkan/ menerapkan kompetensi hasil belajar dalam kehidupan sehari-hari. Dalam pembelajaran ini peserta didik harus dapat mengembangkan ketrampilan dan pemahaman konsep matematika untuk menerapkannya dalam kehidupan sehari-hari. Pengajaran matematika mempunyai tujuan yang sangat luas, salah satu tujuannya adalah agar peserta didik memiliki keterampilan menghubungkan matematika dengan kehidupan seharihari dan menerapkannya dalam soal-soal. Dengan demikian penggunaan model pembelajaran CTL perlu diberikan oleh guru dalam proses belajar, agar dapat mencapai hasil belajar yang lebih baik. Belajar dengan model pembelajaran CTL akan mampu mengembangkan kemampuan peserta didik dalam menyelesaikan masalahmasalah serta mengambil keputusan secara objektif dan rasional. Disamping itu juga akan mampu mengembangkan kemampuan berfikir kritis, logis, dan analitis. Karena itu peserta didik harus benar-benar dilatih dan dibiasakan berfikir secara kritis dan mandiri. Dengan menggunakan model pembelajaran CTL diharapkan peserta didik mampu menyelesaikan soalsoal matematika. Penerapan model pembelajaran CTL dalam pembelajaran matematika khususnya materi Peluang melibatkan peserta didik untuk dapat berperan aktif dengan bimbingan guru, agar peningkatan kemampuan peserta didik dalam memahami konsep dapat terarah lebih baik.Bertitik tolak dari latar belakang permasalahan tersebut di atas maka (1 Peserta didik mengalami kesulitan pada materi program linear. (2)Peserta didik belum mampu memahami, menafsirkan dan mengaplikasikan konsep Peluang. (3) Pembelajaran konvensional mengarah pada terselesainya suatu materi tanpa memperhatikan partisipasi dari peserta didik. Akar penyebab munculnya permasalahan tersebut adalah guru sebagai fasilitator, dalam tahap persiapan maupun tahap penyampaian materi ajar kurang melibatkan peserta didik dalam situasi optimal untuk belajar, cenderung pembelajaran berpusat pada guru dan klasikal akibatnya, peserta didik kurang mampu menangkap ide soal yang kemudian ditampilkan dalam kalimat matematika dengan simbol-simbol. Guru sebagai fasilitator dalam tahap penyampaian materi maupun dalam tahap pelatihan kurang membimbing kerja kelompok dalam menganalisis permasalahan soal cerita matematika sehingga pemahaman peserta didik terhadap konsep matematika yang dipelajari kurang optimal. Dalam tahap pelatihan maupun dalam tahap penampilan hasil, guru jarang meminta peserta didik saling menjelaskan proses pemecahan masalah, hal ini menyebabkan peserta didik mengalami kelemahan dalam melakukan pemecahan masalah.Berdasarkan pada latar belakang tersebut, maka masalah yang timbul dalam penelitian ini adalah adakah peningkatan kemampuan peserta didik dalam memahami konsep program linear dengan model pembelajaran berbasis Contextual Teaching and Learning (CTL) mencapai 65\%, Untuk mengetahui hasil tersebut digunakan indikator sebagai berikut: menjawab pertanyaan guru / mengerjakan soal ke depan; Mengajukan pertanyaan / tanggapan pada guru; 
Memberikan tanggapan atas jawaban peserta didik lain; Mengerjakan soal ke depan. Tingkat pemahaman konsep berhitung pecahan peserta didik yang dapat dilihat dari hasil jawaban peserta didik dalam mengerjakan soal yang diberikan setiap putaran. Hal ini dapat menggunakan kriteria sebagai berikut: Kemampuan mengkonstruksikan soal ke dalam model matematika, Ketepatan dalam menjawab, Proses perhitungan untuk mencari jawaban. Apakah tindakan-tindakan dalam pembelajaran CTL dapat meningkatkan hasil belajar peserta didik pada materi Peluang mencapai 65\%.Berdasarkan rumusan masalah di atas,maka tujuan penelitian ini adalah untuk mengetahui tingkat pengusasaan materi pelajaran Matematika materi Peluang yang telah dipelajari pada peserta didik, mengetahui pengaruh metode belajar aktif meninjau kembali kesulitan dengan model pembelajaran berbasis masalah pelajaran Matematika materi Peluang pada peserta didik Kelas IX E SMP Negeri 33 Surabaya.

Manfaat bagi Sekolah sebagai penentu kebijakan dalam upaya meningkatkan prestasi belajar peserta didik hususnya pada mata pelajaran Matematika dan bagi guru, sebagai bahan pertimbangan dalam menentukan Model Pembelajaran yang dapat memberikan manfaat bagi peserta didik. Penjelasan Istilah (1) Metode Contextual Teaching and Learning adalah: Pengajaran dengan pendekatan Contextual Teaching and Learning adalah suatu pandekatan pengajaran yang menggunakan masalah dunia nyata sebagai suatu konteks bagi peserta didik untuk belajar tentang cara berpikir kritis dan keterampilan pemecahan masalah, serta untuk memperoleh pengetahuan dan konsep yang esensial dari materi pelajaran.(2) Motivasi belajar adalah:Merupakan daya penggerak psikis dari dalam diri seseorang untuk dapat melakukan kegiatan belajar dan menambah keterampilan, pengalaman. Motivasi mendorong dan mengarah minat belajar untuk tercapai suatu tujuan. (3) Prestasi belajar adalah: Hasil belajar yang dinyatakan dalam bentuk nilai atau dalam bentuk skor, setelah peserta didik mengikuti pelajaran matematika. Batasan Masalah: (1) Penelitian ini hanya dikenakan pada peserta didik Kelas IX E SMP Negeri 33 Surabaya.(2) Penelitian ini dilaksanakan pada bulan September semester ganjil tahun pelajaran 2013/2014.(3) Materi yang disampaikan adalah Peluang.

\section{METODE}

Penelitian ini merupakan penelitian tindakan (action research), karena penelitian dilakukan untuk memecahkan masalah pembelajaran di kelas. Penelitian ini juga termasuk penelitian deskriptif, sebab menggambarkan bagaimana suatu teknik pembelajaran diterapkan dan bagaimana hasil yang diinginkan dapat dicapai. Menurut Oja dan Sumarjan (dalai Titik Sugiarti, 1997; 8) mengelompokkan penelitian tindakan menjadi empat macam yaitu (a) guru bertindak sebagai peneliti, (b) penelitian tindakan kolaboratif, (c) Simultan terintegratif, dan (d) administrasi social ekperimental.Dalam penelitian tindakan ini menggunakan bentuk guru sebagai peneliti, penanggung jawab penuh penelitian tindakan adalah praktisi (guru). Tujuan utama dari penelitian tindakan ini adalah meningkatkan hasil pembelajaran di kelas dimana guru secara penuh terlibat dalam penelitian mulai dari perencanaan, tindakan, pengamatan dan refleksi.Dalam penelitian ini peneliti tidak bekerjasama dengan siapapun, kehadiran peneliti sebagai guru di kelas sebagai pengajar tetap dan dilakukan seperti biasa, sehingga peserta didik tidak tahu kalau diteliti. Dengan cara ini diharapkan didapatkan data yang seobjektif mungkin demi kevalidan data yang diperlukan.

Tempat penelitian adalah tempat yang digunakan dalam melakukan penelitian untuk memperoleh data yang diinginkan. Penelitian ini bertempat di SMP Negeri 33 Surabaya, Kota Surabaya Tahun Pelajaran 2013/2014,waktu penelitian adalah waktu berlangsungnya penelitian atau saat penelitian ini dilangsungkan. Penelitian ini dilaksanakan pada bulan September semester I Tahun Pelajaran 2013/2014, subyek penelitian adalah peserta didik-siswi Kelas IX E SMP Negeri 33 Surabaya, Kota Surabaya tahun pelajaran 2013/2014.Penelitian ini menggunakan Penelitian Tindakan Kelas (PTK). Menurut Tim Pelatih Proyek PGSM, PTK adalah suatu bentuk kajian yang bersifat reflektif oleh pelaku tindakan yang dilakukan untuk meningkatkan kemantapan rasional dari tindakan mereka dalam melaksanakan tugas, memperdalam pemahaman terhadap tindakan-tindakan yang penyertaannya adalah menumbuhkan budaya meneliti di kalangan guru (Mukhlis, 2000: 5).Sesuai dengan jenis penelitian yang dipilih, yaitu penelitian tindakan, maka penelitian ini menggunakan model penelitian tindakan dari Kemmis dan Taggart (dalam Sugiarti, 1997: 6), yaitu berbentuk spiral dari sklus yang satu ke siklus yang berikutnya. Setiap siklus meliputi planning (rencana), action (tindakan), observation (pengamatan), dan reflection (refleksi). Langkah pada siklus berikutnya adalah perencanaan yang sudah direvisi, tindakan, pengamatan, dan refleksi. Sebelum masuk pada siklus 1 dilakukan tindakan pendahuluan yang berupa identifikasi permasalahan. Siklus spiral dari tahap-tahap penelitian tindakan kelas dapat dilihat pada gambar berikut. dilakukan itu, serta memperbaiki kondisi dimana praktek pembelajaran tersebut dilakukan. Sedangkah menurut Mukhlis (2000: 5) PTK adalah suatu bentuk kajian yang bersifat sistematis reflektif oleh pelaku tindakan untuk memperbaiki kondisi pembelajaran yang dilakukan.

Adapun tujuan utama dari PTK adalah untuk memperbaiki/meningkatkan pratek pembelajaran secara berkesinambungan, sedangkan tujuan penyertaannya adalah menumbuhkan budaya meneliti di kalangan guru (Mukhlis, 2000: 5).Sesuai dengan jenis penelitian yang dipilih, yaitu penelitian tindakan, maka penelitian ini menggunakan model penelitian tindakan dari Kemmis dan Taggart (dalam Sugiarti, 1997: 6), yaitu berbentuk spiral dari sklus yang satu ke siklus yang berikutnya. Setiap siklus meliputi planning (rencana), action (tindakan), observation (pengamatan), dan reflection (refleksi). Langkah pada siklus berikutnya adalah perencanaan yang sudah direvisi, tindakan, pengamatan, dan refleksi. Sebelum masuk pada siklus 1 dilakukan tindakan pendahuluan yang berupa identifikasi 
permasalahan. Siklus spiral dari tahap-tahap penelitian tindakan kelas dapat dilihat pada gambar berikut.

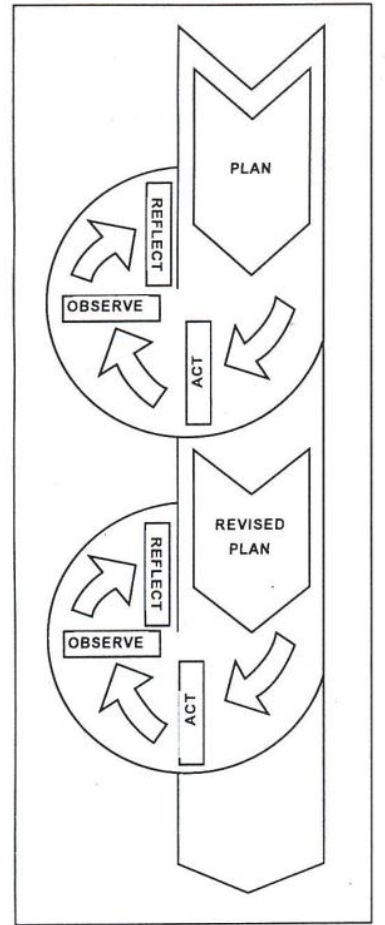

Gambar 3.1 Alur PTK

Penjelasan alur di atas adalah: (1) Rancangan/rencana awal, sebelum mengadakan penelitian peneliti menyusun rumusan masalah, tujuan dan membuat rencana tindakan, termasuk di dalamnya instrumen penelitian dan perangkat pembelajaran.(2) Kegiatan dan pengamatan, meliputi tindakan yang dilakukan oleh peneliti sebagai upaya membangun pemahaman konsep peserta didik serta mengamati hasil atau dampak dari diterapkannya model pembelajaran model Contextual Teaching and Learning. (3)Refleksi, peneliti mengkaji, melihat dan mempertimbangkan hasil atau dampak dari tindakan yang dilakukan berdasarkan lembar pengamatan yang diisi oleh pengamat. (4)Rancangan/rencana yang direvisi, berdasarkan hasil refleksi dari pengamat membuat rancangan yang direvisi untuk dilaksanakan pada siklus berikutnya. Observasi dibagi dalam 2 putaran, yaitu putaran 1 dan 2, dimana masing-masing putaran dikenai perlakuan yang sama (alur kegiatan yang sama) dan membahas satu sub pokok bahasan yang diakhiri dengan tes formatif di akhir masing putaran. Dibuat dalam dua putaran dimaksudkan untuk memperbaiki membandingkan sistem pengajaran yang telah dilaksanakan.

\section{Rencana Tindakan}

Untuk memecahkan masalah penelitian diperlukan langkah yang tepat dalam penanganannya. Sesuai dengan jenis penelitian yang dipilih yaitu penelitian tindakan kelas (PTK) dengan menggunakan pendekatan Contextual Teaching and Learning maka pelaksanaan tindakan direncanakan dalam dua siklus.
Siklus pertama dilaksanakan dengan kompetensi dasar menentukan ruang sampel suatu percobaan, sedangkan siklus kedua dilaksanakan dengan kompetensi dasar menentukan peluang suatu kejadian sederhana a. Setiap siklus terdiri atas satu pertemuan. Langkahlangkah yang secara umum digunakan untuk memecahkan masalah adalah membuat perencanaan yang memuat : (1) Membuat Rencana Pelaksanaan Pembelajaran yang berbasis model pembelajaran Contextual Teaching and Learning. Dalam rencana pembelajaran yang dibuat menggunakan media yang ada disekitar peserta didik itu sendiri dan mudah diperoleh.(2) Menyiapkan/Membuat alat bantu mengajar yang mendukung terlaksananya pembelajaran Contextual Teaching and Learning, meliputi dadu dan uang logam. (3) Membuat instrumen untuk merekam bentuk aktifitas peserta didik selama proses pembelajaran (lembar observasi), penilaian tingkat motivasi (kuesioner). Penilaian hasil belajar peserta didik dilakukan pada setiap akhir siklus. (4)Personil yang dilibatkan dalam penelitian ini selain peserta didik adalah peneliti sendiri sebagai pelaksana tindakan dan seorang supervisor. (5) Refleksi pelaksanaan proses pembelajaran dilakukan pada setiap akhir kegiatan pembelajaran dan pada akhir setiap siklus.(6)Penelitian tindakan dilakukan melalui dua siklus. Adapun mengenai pelaksanaan tindakan melalui tahapan sebagai berikut : (a) Tahap Persiapan (1) Mengidentifikasi Masalah( 2). Membuat Rencana Pelaksanaan Pembelajaran.(3). Menyusun format observasi dan instrumen penelitian.(4). Menetapkan jenis data yang akan dikumpulkan dan teknis analisis data yang digunakan dalam PTK ini. (b) Tahap Implementasi Tindakan.

\section{SIKLUS I}

(a) Perencanaan: Mengidentifikasi masalah pembelajaran,Penyiapan perangkat pembelajaran berupa skenario pembelajaran ,Penyiapan media pembelajaran,Penyiapan bahan dan alat pembelajaran,Penyiapan instrumen observasi pembelajaran,Penyiapan instrumen evaluasi pembelajaran,Penyiapan instrumen refleksi pembelajaran (b) Pelaksanaan tindakan dan observasi : (1). Pengenalan dan tanya jawab mengenai masalah-masalah dalam pembelajaran matematika. (2). Peserta didik berkelompok untuk mencermati masalah-masalah nyata yang dibuat guru dan mendiskusikan penyelesaiannya bersama. (3). Peserta didik mulai menyusun kalimat matematika dan penyelesaiannya yang bisa mereka buat bersama kelompoknya.(4). Peserta didik melaporkan hasilnya di depan kelas dan peserta didik lain menanggapi. Pada tahap observasi dan monitoring, dilakukan observasi dan monitoring serta evaluasi terhadap pelaksanaan tindakan yang telah dilakukan.

(c) Evaluasi dan refleksi, Evaluasi dilakukan dengan memberikan tes dan tugas menyelesaikan soal yang berdasarkan masalah nyata dengan benar. Tes digunakan untuk mengungkap tingkat kemampuan peserta didik mengenai ide dan konsep matematika dalam masalahmasalah nyata dan penyelesaiannya dengan baik atau tepat antara sebelum dan sesudah tindakan. Hasil refleksi 
siklus I ini digunakan untuk merancang pembelajaran di siklus II.

\section{SIKLUS II}

(a) Perencanaan: Mengidentifikasi masalah pembelajaran hasil refleksi pada siklus I, Penyiapan perangkat pembelajaran berupa skenario pembelajaran yang telah disempurnakan, Penyiapan media pembelajaran, Penyiapan bahan dan alat pembelajaran,Penyiapan instrumen observasi pembelajaran,Penyiapan instrumen evaluasi pembelajaran, Penyiapan instrumen refleksi pembelajaran (b) Pelaksanaan tindakan dan observasi : Peserta didik membuat lagi kalimat matematika dan penyelesaiannya dari masalah-masalah lainnya yang bisa dibuatnya secara individu berdasarkan kemampuannya. Caranya peserta didik melihat terlebih dahulu permasalahan sekitar. Kemudian peserta didik menuliskan ke dalam kalimat matematika tentang masalah tersebut. Masalah bisa diambil dari pengalaman dahulu peserta didik atau yang sedang dirasakannya, Peserta didik menceritakan cara menyelesaikan masalah nyata melalui kalimat matematika yang telah dibuatnya dan menuliskannya di papan tulis,Peserta didik lain dipersilahkan menanggapi atau bertanya mengenai cara menyelesaikan masalah tersebut,Guru tidak lupa melakukan evaluasi baik proses maupun produk berupa kalimat matematika yang dibuat anak maupun tentang cara menyelesaikannya,Guru memberikan penguatan sebagai kesimpulan dari pembelajaran saat itu,Guru bersama peserta didik mengadakan refleksi untuk mngetahui kesan-kesan atau respon peserta didik terhadap pembelajaran yang baru saja berlangsung. Pada tahap observasi dan monitoring, dilakukan observasi dan monitoring serta evaluasi terhadap pelaksanaan tindakan yang telah dilakukan. Kriteria keberhasilan tindakan adalah bahwa para peserta didik mampu menyelesaikan masalah-masalah nyata dengan kalimat matematika

(c) Evaluasi dan refleksi : Evaluasi dilakukan dengan memberikan tes dan tugas menyelesaikan soal yang berdasarkan masalah nyata dengan benar. Tes digunakan untuk mengungkap tingkat pemahaman peserta didik mengenai ide dan konsep matematika dalam masalahmasalah nyata dan penyelesaiannya dengan baik atau tepat antara sebelum dan sesudah tindakan Hasil refleksi siklus II ini digunakan untuk menarik kesimpulan.

(d)Tahap Observasi dan Monitoring :Pada tahap observasi dan monitoring, dilakukan observasi dan monitoring serta evaluasi terhadap pelaksanaan tindakan yang telah dilakukan. Kriteria keberhasilan tindakan adalah bahwa para peserta didik mampu menyelesaikan masalah-masalah nyata dengan kalimat matematika. Evaluasi dilakukan dengan memberikan tes dan tugas menyelesaikan soal yang berdasarkan masalah nyata dengan benar.

(e) Tahap Analisis dan Refleksi :Pada tahap ini dilakukan analisis, sintesis dan memaknai hasil tindakan pertama untuk kemudian disimpulkan apakah perlu merevisi gagasan umum atau mungkin memikirkan dan merencanakan kembali jenis tindakan berikutnya yang perlu diterapkan agar peserta didik dapat mudah mempelajari matematika dengan baik. Begitu seterusnya sampai tindakan ini tercapai. Dalam implementasi tindakan ini guru menggunakan metode dan teknik pembelajaran tanya jawab, ceramah, observasi, tugas, kerja kelompok, diskusi, presentasi, dan konstruktvisme.

Instrumen yang digunakan dalam penelitian ini terdiri dari :

(1) Silabus :yaitu seperangkat rencana dan pengaturan tentang kegiatan pembelajaran pengelolahan kelas, serta penilaian hasil belajar.

(2) Rencana Pelajaran (RP) :yaitu merupakan perangkat pembelajaran yang digunakan sebagai pedoman guru dalam mengajar dan disusun untuk tiap putaran. Masing-masing RP berisi kompetensi dasar, indikator pencapaian hasil belajar, tujuan pembelajaran khusus, dan kegiatan belajar mengajar

(3)Lembar Kegiatan Peserta didik :Lembar kegaian ini yang dipergunakan peserta didik untuk membantu proses pengumpulan data hasil eksperimen.

(4)Tes formatif : Tes ini disusun berdasarkan tujuan pembelajaran yang akan dicapai, digunakan untuk mengukur kemampuan pemahaman konsep Matematika pada yang telah dipelajari selama ini. Tes formatif ini diberikan setiap akhir putaran. Bentuk soal yang diberikan adalah pilihan ganda (objektif).

\section{Metode Pengumpulan Data}

Pengumpulan data merupakan prosedur yang sistematik untuk memperoleh data mengenai masalah penelitian yang ingin dipecahkan. Adapun teknik pengumpulan data dalam penelitian ini adalah:

(1) Observasi (pengamatan), Observasi merupakan pengamatan dan pencatatan yangsistematis terhadap gejala-gejala yang diteliti (Usman, 2009:52). Sedangkan Nazir (2005:175) menerangkan bahwa pengumpulan data dengan observasi langsung atau pengamatan langsung adalah cara pengambilan data dengan menggunakan mata tanpa menggunakan alat standaar lain untuk keperluan tersebut. Observasi yang dilakukan dalam penelitian ini adalah observasi secara langsung terhadap fenomena yang diteliti. Dalam teknik ini, peneliti secara langsung mengamati kegiatan belajar mengajar dengan menggunakan model pembelajaran CTL yang digunakan oleh guru matematika kelas IX E SMP Negeri 33 Surabaya, dimana sebelumnya peneliti sudah membuat chek list atau pedoman pengamatan yang tersusun secara sistematis dan mempunyai tujuan yang jelas.

(2) Wawancara, Wawancara merupakan cara yang digunakan oleh peneliti dengan mewawancarai informan secara langsung. Wawancara yang digunakan dalam penelitian ini adalah wawancara mendalam. Metode ini dilakukan dengan tujuan mendapatkan data yang lebih mendalam tentang model pembelajaran CTL dalam proses belajar mengajar mata pelajaran matematika kelas IX E pada pokok bahasan Peluang di SMP Negeri 33 Surabaya. Dalam penelitian ini peneliti menggunakan alat pengumpul data yang berupa pertanyaan yang ditujukan kepaada guru matematika dan peserta didik kelas IX E SMP Negeri 33 Surabaya.

(3)Dokumentasi, Dokumentasi merupakan teknik pengumpulan data yang dilakukan oleh peneliti dengan cara mengumpulkan semua bahan-bahan yang terkait 
dengan penelitian. Metode dokumentasi yang digunakan dalam penelitian ini adalah dengan mengumpulkan bahan berupa data-data, arsip, dokumentasi mengenai gambaran umum sekolah yang meliputi jumlah peserta didik, jumlah guru dan staf karyawan, profil sekolah, visi dan misi sekolah, sarana dan prasarana sekolah, dan foto-foto yang berkaitan dengan penelitian ini, serta data-data mengenai perangkat pembelajaran guru matematika kelas IX yang meliputi prota, promes, silabus, RPP, daftar nilai peserta didik dan komponen lainnya.

\section{Teknik Analisis Data}

Untuk mengetahui keefektifan suatu metode dalam kegiatan pembelajaran perlu diadakan analisa data. Pada penelitian ini menggunakan teknik analisis deskriptif kualitatif, yaitu suatu metode penelitian yang bersifat menggambarkan kenyataan atau fakta sesuai dengan data yang diperoleh dengan tujuan untuk mengetahui prestasi belajar yang dicapai peserta didik juga untuk memperoleh respon peserta didik terhadap kegiatan pembelajaran serta aktivitas peserta didik selama proses pembelajaran.

Untuk mengalisis tingkat keberhasilan atau persentase keberhasilan peserta didik setelah proses belajar mengajar setiap putarannya dilakukan dengan cara memberikan evaluasi berupa soal tes tertulis pada setiap akhir putaran.

\section{Teknik Penilaian}

Prinsip penilaian terhadap keberhasilan belajar peserta didik bukan hanya untuk ujian tetapi juga untuk memecahkan problem kehidupan. Dengan demikian dekolah mendidik anak bukan sekedar untuk medapat nilai bagus dalam ulangan, tetapi agar mereka mampu memecahkan problem kehidupan yang dihadapinya. Maka untuk mewujudkan hal itu dapat dilakukan dengan cara : (1) Penilaian proses belajar:

(a) Penilaian Afektif (Sikap) : Keaktipan peserta didik (active learning), Penafsiran Peserta didik (interpretation), Bertukar pikiran (negotiation)(Bukti dan data hasil pengamatan lihat perolehan hasil belajar).

(b) Penilaian psikomotor (kecakapan),Dilakukan dengan jalan bertanya langsung disela-sela proses pembelajaran berlangsung dengan maksud untuk mengetahui : kemampuan menyampaikan/memecahkan masalah (problem solving),kemampuan bekerja sama (cooperative), kemampuan meyelidiki (inkuiri)

(c).Penilaian kognetif,dilaksanakan pada akhir proses pembelajaran dengan maksud untuk mengetahui seberapa jauh keberhasilan pencapaian kemampuan dasar (bukti dan hasil belajar kognetif dan psikomotor lihat tabel). (2)Penilaian hasil belajar,Penilaian hasil belajar dilakukan melalui ulangan harian(apabiladalam 1 materi sudah selesai dibuka). Penilaian ini dilakukan dengan cara : (a)Penilaian dan hasil belajar psikomotor dilakukan melalui sejumlah tagihan dengan bentuk soal menjelaskan. (b).Penilaian dan hasil belajar kognetif dilakukan melalui sejumlah tagihan dengan bentuk soal pilihan ganda.

\section{Hasil Penelitian}

Siklus 1 dilaksanakan selama 1 hari yaitu pada minggu pertama bulan Oktober (7 Oktober 2013) dengan Kompetensi Dasar : "Menentukan ruang sampel suatu percobaan. Pembelajaran dirancang untuk satu kali pertemuan (4 x 35 menit). Jumlah peserta didik yang mengikuti pembelajaran siklus 1 sebanyak 37 peserta didik yang terdiri dari 17 peserta didik laki-laki dan 20 peserta didik perempuan.

Adapun tahapan pada tiap pertemuan yang dilakukan adalah sebagai berikut:

\section{(a) Perencanaan Tindakan}

Pada tahapan ini dilakukan observasi pembelajaran matematika terhadap peserta didik kelas IX E SMP Negeri 33 Surabaya sebanyak 37 peserta didik tepatnya pada Standar Kompetensi : "Menentukan ruang sampel suatu percobaan”. Hasil observasi terhadap peserta didik kelas IX E diperoleh data bahwa terdapat peserta didik dengan kategori motivasi sangat kurang, oleh karena itu peneliti berupaya meningkatkan motivasi belajar siswa dengan menerapkan metode pembelajaran Contextual Teaching and Learning pada pelajaran matematika. Dengan berpedoman pada Kurikulum Tingkat Satuan Pendidikan (KTSP) mata pelajaran matematika, diadakan persiapan untuk siklus pertama sebagai berikut: (1) Memilih Kompetensi Dasar : "Menentukan ruang sampel suatu percobaan" dan membuat indikator serta tujuan pembelajaran yang ingin dicapai oleh guru dalam pembelajaran matematika. (2) Menyusun Rencana Pelaksanaan Pembelajaran (RPP) model pembelajaran CTL. RPP disusun 2 kali pertemuan setiap siklus dengan alokasi waktu masing-masing 2 x 35 menit. (3) Menyiapkan media benda nyata berupa dadu dan uang logam.(4) Setiap kali mengadakan pembelajaran guru sekaligus sebagai peneliti yaitu mempersiapkan, menata dan mengatur ruangan sebaik mungkin sehingga keadaan kelas kondusif untuk belajar matematika.

\section{(b) Pelaksanaan Tindakan}

Pada siklus I pembelajaran dilaksanakan dengan standar kompetensi memahami peluang kejadian sederhana, dengan kompetensi dasar menentukan ruang sampel suatu percobaan. Adapun indikator pencapaian kompetensi pembelajaran pada siklus I sebagai berikut. (1)Menjelaskan pengertian ruang sampel titik sampel suatu percobaan (2)Menentukan ruang sampel suatu percobaan dengan mendata titik sampelnya .Rencana pelaksanan pembelajaran yang dibuat didasarkan atas kondisi obyektif sekolah dan karakteristik peserta didik yang memuat rencana kegiatan kelas yang dirancang sedemikian rupa. Oleh karena itu kegiatan guru berhubungan dengan penggunaan strategi belajar sesuai dengan langkah-langkah atau tahapan pembelajaran yang telah ditetapkan. Guru hanya memberikan motivasi dan penjelasan seperlunya jika peserta didik membutuhkannya. Sedangkan pelaksanaan pembelajaran diarahkan dengan mengemas bahan ajar untuk disajikan sedemikian yang tentunya berhubungan secara fungsional antara materi dan pengalaman nyata yang dialami peserta didik dalam kehidupan sehari-hari. Peserta didik dibiasakan dan diarahkan untuk menemukan sendiri, mengalami sendiri dan memecahkan masalah melalui pengalaman langsung dalam proses belajar. Tempat kegiatan dalam proses belajar ditentukan oleh kelompok masing-masing yang telah diatus sebelumnya.

Kegiatan siklus I dilakukan dengan menggunakan pilarpilar pendekatan Contextual Teaching and Learning 
dengan usaha mengkombinasikan pilar-pilar tersebut sesuai dengan karakteristik bahan ajar. Tampak jelas bahwa tahapan-tahapan kegiatan pembelajaran yang telah dilaksanakan mencerminkan adanya implementasi penggunaan model pembelajaran Contextual Teaching and Learning. Pilar-pilar Contextual Teaching and Learning yang tampak yaitu terbentuknya masyarakat belajar (learning community), yaitu peserta didik belajar dalam kelompok-kelompok kecil, pemodelan (modelling) berupa penjelasan singkat tentang cara penggunaan alat atau cara kerja, konstruktivisme melalui penggunaan alat dan upaya mengaitkan materi pelajaran dengan dunia nyata peserta didik, menemukan (inquiry) dalam bentuk menemukan konsep-konsep matematika melalui pembelajaran dengan menggunakan alat bantu yang ada di sekeliling mereka, bertanya (questioning) atau latihan inquiry melalui tanya jawab, diskusi kelompok/kelas atau pertanyaan yang diberikan oleh guru, refleksi (reflection) dalam bentuk hasil kerja (karya) atau diskusi, dan adanya penilaian (authentic assessment) yang dilaksanakan pada setiap akhir pembelajaran selain daripada penilaian pada setiap akhir siklus.

\section{(c)Observasi}

(1). Motivasi Belajar Peserta Didik Data tentang motivasi belajar peserta didik sebagai hasil pelaksanaan tindakan pada siklus I yang dikumpulkan melalui observasi aktivitas adalah menyangkut berapa besar motivasi peserta didik dalam mengikuti kegiatan belajar mengajar dengan menggunakan model pembelajaran Contextual Teaching and Learning. Data motivasi belajar peserta didik yang diperoleh melalui lembar observasi yang lakukan oleh guru menunjukkan data sebagai berikut:

Tabel 4.1. Hasil Data Observasi Motivasi Belajar Peserta didik Siklus I

\begin{tabular}{|c|l|c|}
\hline No. & \multicolumn{1}{|c|}{ Aktivitas Peserta Didik } & Skor \\
\hline 1 & $\begin{array}{l}\text { Kesiapan siswa untuk menerima } \\
\text { materi pelajaran }\end{array}$ & 118,67 \\
\hline 2 & $\begin{array}{l}\text { Antusiasme siswa dalam } \\
\text { mengikuti kegiatan diskusi } \\
\text { kelompok }\end{array}$ & 119,33 \\
\hline 3 & $\begin{array}{l}\text { Aktivitas siswa dalam kegiatan } \\
\text { diskusi kelompok }\end{array}$ & 117 \\
\hline 4 & $\begin{array}{l}\text { Aktivitas siswa dalam } \\
\text { memecahkan masalah }\end{array}$ & 116,33 \\
\hline 5 & $\begin{array}{l}\text { Aktivitas siswa dalam } \\
\text { mengerjakan soal latihan }\end{array}$ & 108,67 \\
\hline 6 & $\begin{array}{l}\text { Partisipasi siswa dalam menutup } \\
\text { kegiatan pembelajaran }\end{array}$ & 112 \\
\hline & JUMLAH & $\mathbf{6 9 2}$ \\
\hline & RATA2 & $\mathbf{1 1 5 , 3 3}$ \\
\hline & SKOR MAKSIMAL & $\mathbf{6 2 \%}$ \\
\hline \multicolumn{2}{|c|}{ KERSENTASE } \\
\hline
\end{tabular}

Hasil observasi data motivasi belajar peserta didik melalui observasi aktivitas pada akhir siklus I menunjukkan perolehan skor pada aspek kesiapan siswa untuk menerima materi pelajaran sebesar 118,67, antusiasme siswa dalam mengikuti kegiatan diskusi kelompok sebesar 119,33, aktivitas siswa dalam kegiatan diskusi kelompok sebesar 117, aktivitas siswa dalam memecahkan masalah sebesar 116,33, aktivitas siswa dalam mengerjakan soal latihan sebesar 108,67, dan partisipasi siswa dalam menutup kegiatan pembelajaran sebesar 112. Rata-rata aktivitas menunjukkan bahwa 62 persen para peserta didik mempunyai tingkat motivasi belajar yang baik. Skor ratarata motivasi belajar peserta didik 115,33 dapat dikatakan bahwa motivasi belajar kategori cukup. Diagram motivasi belajar peserta didik melalui observasi aktivitas untuk siklus I dapat dilihat pada tabel berikut ini.

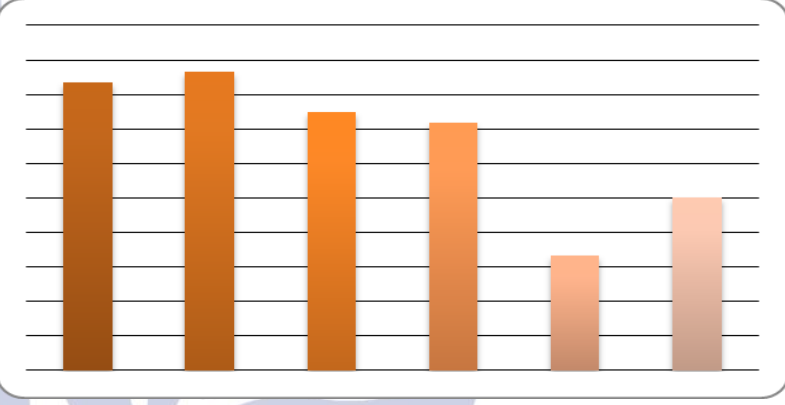

Diagram 4.1. Diagram Motivasi Belajar Siswa Siklus I

Hasil observasi data motivasi belajar peserta didik melalui wawancara sederhana pada akhir siklus I menunjukkan bahwa peserta didik menjadi lebih termotivasi dengan model pembelajaran Contextual Teaching and Learning.

\section{(2). Data Hasil Belajar Peserta Didik}

Berikut ini adalah data hasil belajar peserta didik yang diperoleh dari kuis :

Tabel 4.2 : Data Hasil Belajar Peserta Didik Siklus I

\begin{tabular}{|c|l|c|}
\hline No. & \multicolumn{1}{|c|}{ Uraian } & Hasil \\
\hline 1 & Jumlah & 2570 \\
\hline 2 & Nilai rata-rata & 69,46 \\
\hline 3 & Nilai tertinggi & 80 \\
\hline 4 & Nilai terendah & 50 \\
\hline 5 & Jumlah siswa yang tuntas & 28 \\
\hline 6 & Jumlah siswa yang tidak tuntas & 9 \\
\hline 7 & Persentase siswa yang tuntas & $75,68 \%$ \\
\hline 8 & Persentase siswa yang tidak tuntas & $24,32 \%$ \\
\hline 9 & Daya serap & $69,46 \%$ \\
\hline
\end{tabular}

Hasil observasi data hasil belajar siswa melalui pengamatan pada akhir siklus I menunjukkan perolehan jumlah belajar siswa sebesar 2570 dengan nilai tertinggi 80; nilai terrendah 50, dan rata-rata sebesar 69,46 . Ketuntasan belajar pada siklus I menunjukkan persentase 
sebesar $75,68 \%$, hal ini menunjukkan bahwa 65 persen para siswa telah mencapai kriteria ketuntasan belajar yang ditentukan. Sedangkan siswa yang belum tuntas belajarnya menunjukkan persentase sebesar 24,32\%. Distribusi tabel frekuensi dan persentase motivasi belajar siswa melalui observasi untuk siklus I dapat dilihat pada tabel berikut ini.

Tabel 4.3 : Distribusi Hasil Belajar Peserta Didik Siklus I

\begin{tabular}{|c|l|c|c|c|}
\hline No. & Kriteria Nilai & Nilai & $\begin{array}{c}\text { Jml } \\
\text { Peserta Didik }\end{array}$ & $\begin{array}{c}\text { Persentase } \\
(\%)\end{array}$ \\
\hline 1 & $\begin{array}{l}\text { Sangat } \\
\text { memuaskan }\end{array}$ & $90-100$ & 0 & $0 \%$ \\
\hline 2 & Memuaskan & $80-89$ & 11 & $30 \%$ \\
\hline 3 & Cukup & $70-79$ & 17 & $46 \%$ \\
\hline 4 & $\begin{array}{l}\text { Kurang } \\
\text { memuaskan }\end{array}$ & $60-69$ & 5 & $14 \%$ \\
\hline 5 & $\begin{array}{l}\text { Sangat tidak } \\
\text { memuaskan }\end{array}$ & $50-59$ & 4 & $11 \%$ \\
\hline & Jumlah & & 37 & $100 \%$ \\
\hline
\end{tabular}

\section{(3). Aktivitas Pengelolaan Pembelajaran Guru}

Tabel 4.4. Aktivitas Pengelolaan Pembelajaran oleh Guru Siklus I

\begin{tabular}{|c|l|c|c|}
\hline No. & \multicolumn{1}{|c|}{ Aktivitas Guru } & Skor & Persentase \\
\hline 1 & Persiapan & 15 & $\mathbf{5 0 , 0 0}$ \\
\hline 2 & $\begin{array}{l}\text { Presentasi/Penyampaian } \\
\text { Pembelajaran }\end{array}$ & 28 & $\mathbf{7 7 , 7 8}$ \\
\hline \multirow{2}{*}{3} & $\begin{array}{l}\text { Metode } \\
\text { Pembelajaran/Pelaksanaan } \\
\text { Pembelajaran }\end{array}$ & 30 & $\mathbf{6 8 , 1 8}$ \\
\hline 4 & Karakteristik Pribadi Guru & 20 & $\mathbf{8 3 , 3 3}$ \\
\hline \multicolumn{2}{|c|}{ JUMLAH } & $\mathbf{9 3}$ & $\mathbf{2 7 9 , 2 9}$ \\
\hline RATA2 & \multicolumn{2}{|c|}{ Cukup } \\
\hline
\end{tabular}

Pengelolaan aktivitas oleh guru pada pembelajaran Contextual Teaching and Learning pada siklus I tergolong cukup (skor 93) Indikator yang dinilai muncul sangat baik adalah penerapan metode pembelajaran dan pelaksanaan pembelajaran. Namun pada kegiatan ini masih terdapat kekurangan yaitu guru belum dapat melaksanakan beberapa aspek pembelajaran dengan baik, sehingga perlu diperbaiki pada tindakan siklus berikutnya.

(d) Refleksi

Pada tatap muka awal, tampaknya proses pembelajaran masih berjalan secara rutinitas. Belum ada perubahan yang sangat berarti dalam mutu proses. Hal yang cukup menggembirakan adalah munculnya motivasi, minat dan perhatian peserta didik, serta hilangnya ketegangan dan berganti dengan rasa gembira. Pada tatap muka kedua, sudah mulai tampak antusias, kerja sama baik, cukup konsentrasi dalam mengikuti pelajaran, cukup aktif memberikan jawaban atas pertanyaan yang diberikan dan cukup banyak jawaban yang diberikan sudah benar serta cukup terampil menggunakan alat bantu dalam kegiatan pembelajaran. Kelemahan yang terjadi adalah masih banyak peserta didik belum ada keberanian mengajukan pertanyaan dan belum memiliki kemampuan memberikan penjelasan.

Kurang berhasilnya tindakan yang diberikan dalam proses pembelajaran pada siklus I diakibatkan oleh kadar implementasi pilar-pilar Contextual Teaching and Learning yang digunakan belum mencapai tingkat yang optimal. Kondisi nyata yang dihadapi adalah berhubungan langsung masalah-masalah sebagai berikut :Media pembelajaran perlu disempurnakan agar lebih mudah dipahami peserta didik, perlu ditambah untuk lebih menambah variasi,peserta didik yang merasa tidak bisa mengikuti pelajaran cenderung tidak aktif dalam kelompok karena belum beradaptasi, peserta didik perlu banyak dilatih secara rutin agar dapat terbiasa melakukan kegiatan inquiry.

\section{SIKLUS II}

\section{(a) Perencanaan Tindakan.}

Pada siklus II pembelajaran dilaksanakan dengan standar kompetensi memahami peluang kejadian sederhana dengan kompetensi dasar Menentukan peluang suatu kejadian sederhana.Adapun indikator pencapaian kompetensi pembelajaran pada siklus II adalah 1). menghitung peluang masing-masing titik sample pada ruang sample suatu percobaan, dan 2). menghitung nilai peluang suatu kejadian. Berdasarkan hasil refleksi dari pelaksanaan tindakan siklus I masih terdapat beberapa kekurangan mendasar pada diri peserta didik dalam mengikuti proses pembelajaran matematika. Usaha untuk mengatasi kekurangan-kekurangan yang terjadi dilakukan dengan mengadakan perbaikan pada aspek strategi yang digunakan, terutama perlunya latihan inquiry. Model latihan inquiry bertujuan untuk menumbuhkan keberanian peserta didik dan mengemukakan gagasan pada orang lain. Melalui latihan inquiry peserta didik diarahkan untuk berani melakukan presentase atau memberikan penjelasan-penjelasan terhadap suatu hasil karya/kerja. Gagasan pada peserta didik akan muncul bila dalam proses belajar mengajar dilaksanakan untuk menumbuhkan rasa ingin tahu secara optimal dan peserta didik dapat mengontrol dirinya sendiri. Upaya untuk meningkatkan minat, motivasi, konsentrasi, keaktifan menjawab pertanyaan, kerja sama kelompok, ketepatan jawaban yang diberikan maka langkah yang ditempuh adalah mengubah lembar observasi menjadi sebuah paket penilaian untuk setiap peserta didik. Melalui paket penilaian ini peserta didik menyadari bahwa setiap aktifitas yang dilakukan diberikan penghargaan atau nilai sesuai dengan tingkat perubahan setiap aspek yang terjadi pada setiap peserta didik.

\section{(b) Pelaksanaan Tindakan.}

Langkah-langkah kegiatan pembelajaran yang dilakukan tidak terjadi perubahan dan tetap mengacu pada skenario pembelajaran yang telah dibuat. Hanya 
dalam pelaksanaan tindakan difokuskan perbaikan atas kekurangan atau kelemahan yang terjadi pada siklus I.

\section{(a) Observasi}

(1). Motivasi Belajar Peserta didik. Data tentang motivasi belajar peserta didik sebagai hasil pelaksanaan tindakan pada siklus II yang dikumpulkan melalui observasi aktivitas adalah menyangkut seberapa besar motivasi peserta didik dalam mengikuti kegiatan belajar mengajar dengan menggunakan model pembelajaran Contextual Teaching and Learning. Data motivasi belajar peserta didik yang diperoleh melalui lembar observasi yang dilakukan oleh supervisor menunjukkan data sebagai berikut.

Tabel 4.5. Hasil Data Observasi Motivasi Belajar Peserta didik Siklus II

\begin{tabular}{|c|c|c|}
\hline No. & Aktivitas Peserta Didik & Skor \\
\hline 1 & $\begin{array}{l}\text { Kesiapan siswa untuk menerima } \\
\text { materi pelajaran }\end{array}$ & 167 \\
\hline 2 & $\begin{array}{l}\text { Antusiasme siswa dalam } \\
\text { mengikuti kegiatan diskusi } \\
\text { kelompok }\end{array}$ & 168 \\
\hline 3 & $\begin{array}{l}\text { Aktivitas siswa dalam kegiatan } \\
\text { diskusi kelompok }\end{array}$ & 163,67 \\
\hline 4 & $\begin{array}{l}\text { Aktivitas siswa dalam } \\
\text { memecahkan masalah }\end{array}$ & 155,67 \\
\hline 5 & $\begin{array}{l}\text { Aktivitas siswa dalam } \\
\text { mengerjakan soal latihan }\end{array}$ & 161,33 \\
\hline 6 & $\begin{array}{l}\text { Partisipasi siswa dalam menutup } \\
\text { kegiatan pembelajaran }\end{array}$ & 160,33 \\
\hline & JUMLAH & 692 \\
\hline & RATA2 & 115,33 \\
\hline & SKOR MAKSIMAL & 185 \\
\hline & PERSENTASE & $62 \%$ \\
\hline & KRITERIA & Cukup \\
\hline
\end{tabular}

Hasil observasi data motivasi belajar peserta didik melalui observasi aktivitas pada akhir siklus II menunjukkan perolehan skor pada aspek kesiapan siswa untuk menerima materi pelajaran sebesar 167 , antusiasme siswa dalam mengikuti kegiatan diskusi kelompok sebesar 168, aktivitas siswa dalam kegiatan diskusi kelompok sebesar 163,67, aktivitas siswa dalam memecahkan masalah sebesar 155,67, aktivitas siswa dalam mengerjakan soal latihan sebesar 161,33, dan partisipasi siswa dalam menutup kegiatan pembelajaran sebesar 160,33. Rata-rata aktivitas menunjukkan bahwa 88 persen para peserta didik mempunyai tingkat motivasi belajar yang sangat baik. Skor rata-rata motivasi belajar peserta didik 163,59 dapat dikatakan bahwa motivasi belajar kategori sangat baik. Diagram motivasi belajar peserta didik melalui observasi aktivitas untuk siklus I dapat dilihat pada tabel berikut ini.

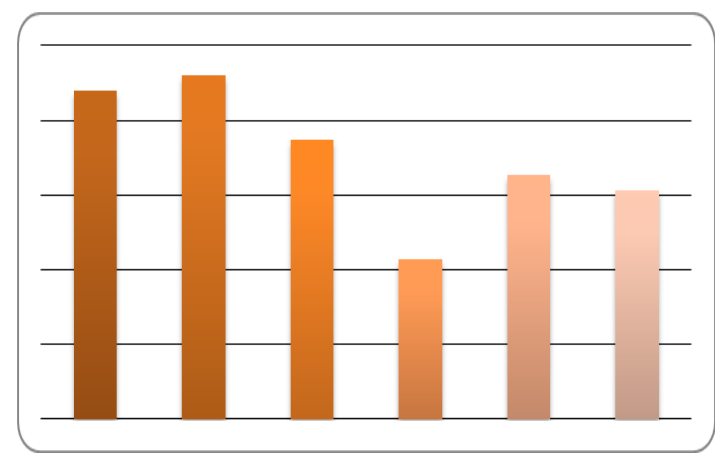

Diagram 4.2. Diagram Motivasi Belajar Siswa Siklus II

Hasil observasi data motivasi belajar peserta didik melalui wawancara sederhana pada akhir siklus II menunjukkan bahwa peserta didik menjadi lebih termotivasi dengan model pembelajaran Contextual Teaching and Learning.

\section{2). Data Hasil Belajar Peserta Didik}

Berikut ini adalah data hasil belajar peserta didik yang diperoleh dari kuis :

Tabel 4.6 : Data Hasil Belajar Peserta Didik Siklus II

\begin{tabular}{|c|l|c|}
\hline No. & \multicolumn{1}{|c|}{ Uraian } & Hasil \\
\hline 1 & Jumlah & 2860 \\
\hline 2 & Nilai rata-rata & 77,30 \\
\hline 3 & Nilai tertinggi & 100 \\
\hline 4 & Nilai terendah & 70 \\
\hline 5 & Jumlah siswa yang tuntas & 37 \\
\hline 6 & Jumlah siswa yang tidak tuntas & 0 \\
\hline 7 & Persentase siswa yang tuntas & $100,00 \%$ \\
\hline 8 & Persentase siswa yang tidak tuntas & $0,00 \%$ \\
\hline 9 & Daya serap & $77,30 \%$ \\
\hline
\end{tabular}

Hasil observasi data hasil belajar siswa melalui pengamatan pada akhir siklus II menunjukkan perolehan jumlah belajar siswa sebesar 2860 dengan nilai tertinggi 100; nilai terrendah 70 , dan nilai rata-rata sebesar 77,30.Ketuntasan belajar pada siklus II menunjukkan persentase sebesar $100 \%$, hal ini menunjukkan bahwa 65 persen para siswa telah mencapai kriteria ketuntasan belajar yang ditentukan.

Distribusi tabel frekuensi dan persentase motivasi belajar siswa melalui observasi untuk siklus II dapat dilihat pada tabel berikut ini.

Tabel 4.7: Distribusi Hasil Belajar Peserta Didik Siklus II

\begin{tabular}{|c|l|c|c|c|}
\hline No. & Kriteria Nilai & Nilai & $\begin{array}{c}\text { Jml } \\
\text { Peserta Didik }\end{array}$ & $\begin{array}{c}\text { Persentase } \\
(\%)\end{array}$ \\
\hline 1 & $\begin{array}{l}\text { Sangat } \\
\text { memuaskan }\end{array}$ & $90-100$ & 8 & $22 \%$ \\
\hline 2 & Memuaskan & $80-89$ & 11 & $30 \%$ \\
\hline 3 & Cukup & $70-79$ & 18 & $49 \%$ \\
\hline 4 & $\begin{array}{l}\text { Kurang } \\
\text { memuaskan }\end{array}$ & $60-69$ & 0 & $0 \%$ \\
\hline
\end{tabular}




\begin{tabular}{|c|l|c|c|c|}
\hline No. & Kriteria Nilai & Nilai & $\begin{array}{c}\text { Jml } \\
\text { Peserta Didik }\end{array}$ & $\begin{array}{c}\text { Persentase } \\
(\%)\end{array}$ \\
\hline 5 & $\begin{array}{l}\text { Sangat tidak } \\
\text { memuaskan }\end{array}$ & $50-59$ & 0 & $0 \%$ \\
\hline & Jumlah & & 37 & $100 \%$ \\
\hline
\end{tabular}

\section{(3). Aktivitas Pengelolaan Pembelajaran Guru}

Tabel 4.8. Aktivitas Pengelolaan Pembelajaran oleh Guru Siklus II

\begin{tabular}{|c|l|c|c|}
\hline No. & \multicolumn{1}{|c|}{ Aktivitas Guru } & Skor & Persentase \\
\hline 1 & Persiapan & 22 & $\mathbf{7 3 , 3 3}$ \\
\hline 2 & $\begin{array}{l}\text { Presentasi/Penyampaian } \\
\text { Pembelajaran }\end{array}$ & 36 & $\mathbf{1 0 0 , 0 0}$ \\
\hline 3 & $\begin{array}{l}\text { Metode } \\
\text { Pembelajaran/Pelaksanaan } \\
\text { Pembelajaran }\end{array}$ & 41 & $\mathbf{9 3 , 1 8}$ \\
\hline 4 & Karakteristik Pribadi Guru & 24 & $\mathbf{1 0 0 , 0 0}$ \\
\hline \multicolumn{2}{|c|}{ JUMLAH } & $\mathbf{9 3}$ & $\mathbf{1 2 3}$ \\
\hline RATA2 & $\mathbf{2 3 , 2 5}$ & $\mathbf{3 0 , 7 5}$ \\
\hline \multicolumn{2}{|c|}{ Sangat Baik } \\
\hline
\end{tabular}

Pengelolaan aktivitas oleh guru pada pembelajaran Contextual Teaching and Learning pada siklus II tergolong cukup (skor 123) Indikator yang dinilai muncul sangat baik adalah penerapan metode pembelajaran dan pelaksanaan pembelajaran. Pada kegiatan ini aktivitas guru telah melaksanakan aspek pembelajaran dengan baik, pada setiap aspek yang dilaksanakan terjadi peningkatan bila dibandingkan pada tindakan siklus sebelumnya.

\section{(d.) Refleksi}

Masalah yang ditemukan pada siklus I telah dapat diatasi pada siklus II. Hal ini dapat dilihat dari adanya peningkatan skor rata-rata motivasi belajar peserta didik dan peningkatan skor rata-rata hasil belajar matematika. Peningkatan tersebut merupakan implikasi peningkatan mutu proses belajar mengajar. Pengaruh positif yang muncul dari penggunaan model pembelajaran Contextual Teaching and Learning dalam pembelajaran sudah dianggap cukup sebagai bukti keberhasilan pelaksanaan pembelajaran. Oleh karena itu siklus pelaksanaan tindakan dapat dihentikan.

\section{Analisis dan Interpretasi Data Motivasi Belajar}

Ada atau tidaknya peningkatan dan hubungan terhadap tindakan pembelajaran yang dilakukan harus didasarkan oleh bukti-bukti kuat. Bukti nyata, menjadi acuan berada pada hasil tindakan pada siklus I dan siklus II. Hasil yang diperoleh pada setiap siklus melalui lembar observasi seperti tampak pada tabel berikut ini.
Diagram 4.3. Diagram Observasi Motivasi Siswa Siklus I dan II

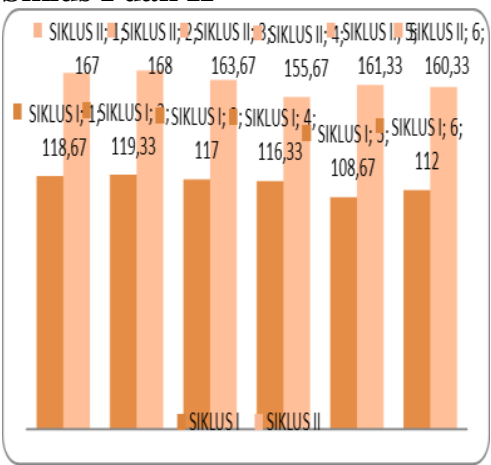

1. Kesiapan siswa untuk menerima materi pelajaran.

2. Antusiasme siswa dalam mengikuti kegiatan diskusi kelompok

3. Aktivitas siswa dalam kegiatan diskusi kelompok

4. Aktivitas siswa dalam memecahkan masalah

5. Aktivitas siswa dalam mengerjakan soal latihan

6. Partisipasi siswa dalam menutup kegiatan pembelajaran

Keterangan : Hasil belajar yang diperoleh pada setiap siklus melalui observasi tampak pada diagram berikut ini.

Diagram 4.4. Diagram Observasi Distribusi Hasil Belajar Siswa Siklus I dan II

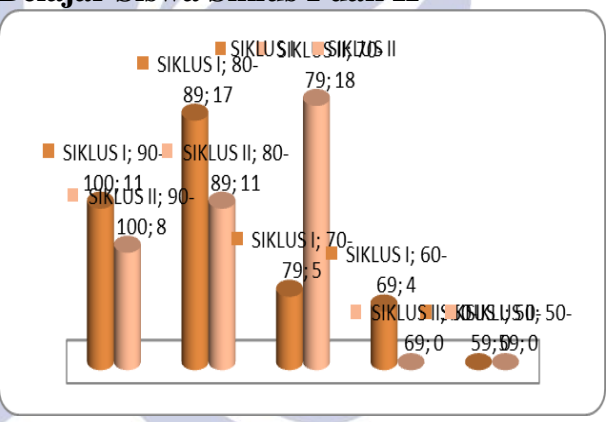

Berdasarkan informasi dari kegiatan wawancara sederhana pada siklus I dan siklus II, pembelajaran matematika dengan model pembelajaran Contextual Teaching and Learning menunjukkan adanya peningkatan motivasi belajar peserta didik.

\section{PEMBAHASAN}

Berdasarkan informasi dari kegiatan wawancara sederhana, pembelajaran matematika dengan model pembelajaran Contextual Teaching and Learning menunjukkan adanya peningkatan motivasi belajar peserta didik. Secara keseluruhan dapat disimpulkan bahwa berdasarkan hasil analisis deskriptif ternyata terdapat peningkatan motivasi belajar dalam pengajaran matematika dengan menggunakan pendekatan Contextual Teaching and Learning. Hal ini dapat dilihat pada peningkatan rata-rata motivasi belajar pada siklus I dan II dapat menjadi bukti pendukung yang cukup berarti tentang kebermaknaan penggunaan model pembelajaran Contextual Teaching and Learning dalam meningkatnya motivasi belajar matematika peserta didik. 
Peningkatan motivasi belajar peserta didik dalam pengajaran matematika kelas IX E SMP Negeri 33 Surabaya memberikan indikasi yang kuat terhadap meningkatnya mutu proses pembelajaran yang dilaksanakan. Oleh karena itu pembelajaran dengan model pembelajaran Contextual Teaching and Learning selain meningkatkan motivasi belajar juga dapat meningkatkan mutu proses pembelajaran, matematika secara signifikan.

Adapun hambatan yang menjadi penyebab kurang berhasilnya tindakan yang diberikan dalam proses pembelajaran diakibatkan oleh kadar implementasi pilarpilar Contextual Teaching and Learning yang digunakan belum mencapai tingkat yang optimal. Kondisi nyata yang dihadapi adalah berhubungan langsung masalahmasalah sebagai berikut.

- Media pembelajaran perlu di sempurnakan agar lebih mudah dipahami peserta didik.

- Media pembelajaran perlu ditambah untuk lebih menambah variasi

- Peserta didik yang merasa tidak bisa mengikuti pelajaran cenderung tidak aktif dalam kelompok karena belum beadaptasi

- Peserta didik perlu banyak dilatih secara rutin agar dapat terbiasa melakukan kegiatan inquiry.

\section{PENUTUP}

\section{Simpulan}

Dari hasil kegiatan pembelajaran yang telah dilakukan dan berdasarkan seluruh pembahasan serta analisis yang telah dilakukan dapat disimpulkan sebagai berikut: (1) pembelajaran dengan metode Contextual Teaching and Learning pada materi pelajaran memiliki dampak positif dalam meningkatkan prestasi belajar peserta didik yang ditandai dengan peningkatan ketuntasan belajar peserta didik,(2) penerapan metode Contextual Teaching and Learning pada materi pelajaran mempunyai pengaruh positif, yaitu dapat meningkatkan motivasi belajar peserta didik yang ditunjukan dengan rata-rata jawaban peserta didik yang menyatakan bahwa peserta didik tertarik dan berminat dengan metode Contextual Teaching and Learning pada materi pelajaran sehingga mereka menjadi termotivasi untuk belajar,(3) penerapan metode Contextual Teaching and Learning pada materi pelajaran efektif untuk mengingatkan kembali materi ajar yang telah diterima peserta didik selama ini, sehingga mereka merasa siap untuk menghadapi ujian kenaikan kelas yang segera akan dilaksanakan.

\section{Saran}

Dari hasil penelitian yang diperoleh dari uraian sebelumnya agar proses belajar mengajar Matematika lebih efektif dan lebih memberikan hasil yang optimal bagi peserta didik, makan disampaikan saran sebagai berikut:(1) Untuk melaksanakan metode Contextual Teaching and Learning pada materi pelajaran memerlukan persiapan yang cukup matang, sehingga guru harus mempu menentukan atau memilih topik yang benarbenar bisa diterapkan dengan metode Contextual Teaching and Learning pada materi pelajaran proses belajar mengajar sehingga diperoleh hasil yang optimal.(2)Dalam rangka meningkatkan prestasi belajar peserta didik, guru hendaknya lebih sering melatih peserta didik dengan berbagi metode, walau dalam taraf yang sederhana, dimana peserta didik nantinya dapat menemuan pengetahuan baru, memperoleh konsep dan keterampilan, sehingga peserta didik berhasil atau mampu memecahkan masalah-masalah yang dihadapinya.(3)Perlu adanya penelitian yang lebih lanjut, karena hasil penelitian ini hanya dilakukan di SMP Negeri 33 Surabaya, Kota Surabaya tahun pelajaran 2013/2014.

\section{DAFTAR PUSTAKA}

Arikunto, Suharsimi. 2002. Prosedur Penelitian Suatu Pendekatan Praktek. Jakarta: Rineksa Cipta.

Ali, Muhammad. 1996. Guru Dalam Proses Belajar Mengajar. Bandung: Sinar Baru Algesindon.

Hadi, Sutrisno. 1982. Metodologi Research, Jilid 1. Yogyakarta: YP. Fak. Psikologi UGM.

Lee, W.R. 1985. Language Teaching Games and Contests. London: Oxfortd University Press.

Melvin, L. Siberman. 2004. Aktif Learning, 101 Cara Belajar Peserta didik Aktif. Bandung: Nusamedia dan Nuansa.

Sudjana, Nana. 1989. Dasar-dasar Proses Belajar Mengajar. Bandung: Sinar Baru.

Sukmadinata, Nana Syaodih. 2004. Metode Penelitian Pendidikan. Bandung: PT. Remaja Rosdakarya.

Surakhmad, Winarno. 1990. Metode Pengajaran Nasional. Bandung: Jemmars.

Weed, Gretchen, E. 1971. Using Games in Teaching Children. ELEC Bulletin No. 32. Winter. Tokyo. Japan.

Rudi Hartono.2014. Ragam Mengajar Yang Mudah Diterima Murid. Jogyakarta: DIVA Press.

Trianto.2008. Mendesains Pembelajaran Kontekstual ( Contextual Teaching And Learning) Di Kelas. Jakarta: Cerdas Pustaka Publisher.

Kunandar. 2008. Guru Profesional Implementasi Kurikulum Tingkat Satuan Pendidikan ( KTSP) dan Sukses dalam Sertifikasi Guru. Jakarta: PT Raja Grafindo Persada.

Udin SaefudinSa'ud. 2008. Inovasi Pendidikan. Bandung: ALFABETA. 
Suharsimi Arikunto, Suhardjono, Supardi. 2016.

Penelitian Tindakan Kelas. Jakarta: PT. Bumi Aksara.

Sukardi. 2015. Metodologi Penelitian Pendidikan. Jakarta: PT Bumi Aksara.

Wina Sanjaya. 2007. Strategi Pembelajaran Beroreintasi Standar Proses Pendidikan. Jakarta : Kencana.

Zubaidah Amir, Risnawati. 2016. Psikologi Pembelajaran Matematika. Yogyakarta : Aswaja Pressindo.

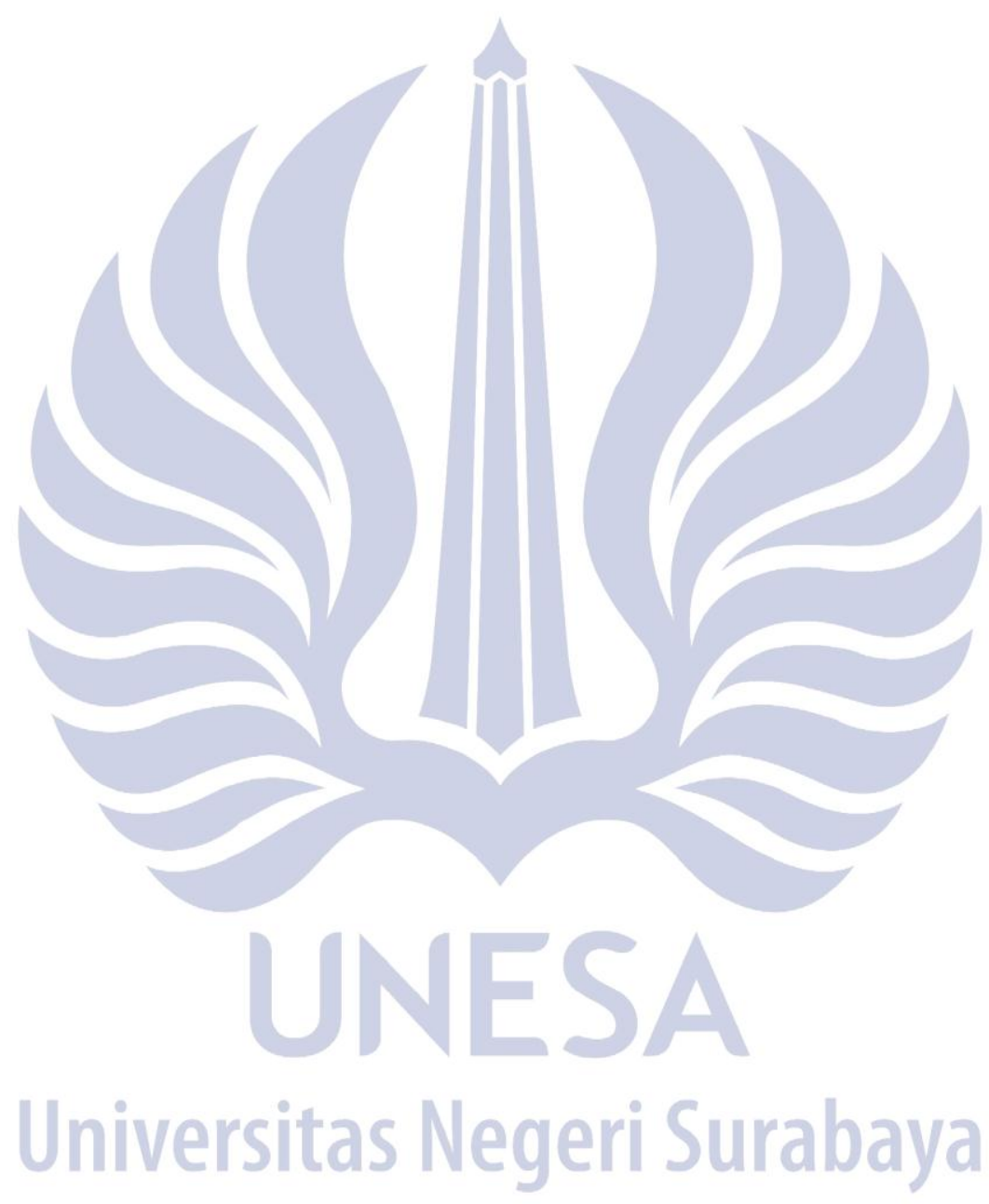

